\title{
A DIALÉTICA DA AÇÃO TRÁGICA NA ANTIGGONA EM HEGEL: UMA ABORDAGEM ARISTOTÉLICA*
}

Clarides Henrich de Barba**

SÍNTESE - A idèia central desse estudo é que a tragédia em Hegel, mesmo que apresenta uma certa novidade sobre a estrutura dialética da ação trágica, ainda está vinculada com a teoria aristotélica apontada na Poética, porque trata sistematicamente dos três elementos qualitativos do trágico. A primeira fase do estudo caracteriza os três elementos da ação trágica em Aristóteles: mito, caráter e pensamento. A segunda fase demonstra o conteúdo da ação trágica na Estética de Hegel. Mas, é preciso estabelecer que Hegel segue Aristóteles não apenas numa análise abstrata, mas também no desenvolvimento concreto da ação trágica. Assim, a terceira fase analisa a função dos três elementos qualitativos da ação trágica em Antígona na Fenomenologia do Espírito. Embora, não é novidade que Hegel utiliza muito das obras de Aristóteles, até agora não foi encontrada uma explicação razoável pela literatura critica sobre a análise hegeliana da teoria aristotélica da ação trágica.

PALAVRAS-CHAVE - Tragédia, Hegel, Estética, Aristóteles, Poética, Antígona.
ABSTRACT - The central idea of that study is to show that the tragedy in Hegel, even if it presents a certain novelty on the dialectic structure of the tragic action, it is still linked with Aristotelian theory pointed in the Poetic, because it is systematically about the three qualitative elements of the tragic. The first phase of the study characterizes the three elements of the tragic action in Aristotle: myth, character and thought. The second phase demonstrates the content of the tragic action in the aesthetics of Hegel. The third phase analyzes the function of the three qualitative elements of the tragic action in Antigone in Phenomenology of Spint.

KEY WORDS - Tragedy, Hegel, Aesthetic, Aristotle, Poetic, Antigone.

* Este trabalho é o resumo da Dissertação de Mestrado em Filosofia na Universidade Federal de Santa Maria - UFSM que possui como título original: "Antígona e a ação trágica em Hegel: uma abordagem aristotélica", tendo sido orientado peio Prof. Dr. Glenn Walter Erickson.

** Mestre em Filosofia na Universidade Federal de Santa Maria - UFSM; Professor do Departamento de Filosofia/Sociologia na Universidade de Rondônia - UNIR, Rondônia.

\begin{tabular}{|c|c|c|c|c|c|}
\hline VERITAS & Porto Alegre & v. 43 & $\mathrm{n}^{\mathrm{0}} 4$ & Dezembro 1998 & p. 985-998 \\
\hline
\end{tabular}




\section{1 - Introdução}

A tragẻdia ${ }^{1}$ nasceu sob o campo da ação. Esta frase, sem dúvida, é a que melhor pode expressar o conteúdo das obras dramáticas. Num processo interativo entre a ação, o sujeito trágico e a influência do divino, o poeta desenvolvia imitações de ações elevadas, consideradas por Aristóteles como artisticamente belas. $\mathrm{Na}$ cultura grega, o trágico surgiu a partir de três condições. A primeira, é que ele provém dos mitos, a segunda, é de que existe no trágico uma relação do homem com o mundo e com o divino, e a terceira é de que o sujeito trágico deve ter consciência de sua própria ação. Contudo, é importante identificar, neste contexto, que a matéria da tragédia é o mito, onde o homem reconhece na ação trágica não apenas respostas para as suas indagações míticas, mas dúvidas que aparecem no interior do espetáculo. Ora, é no espetáculo trágico que aparecem os elementos da máscara, do coro que é representado pela coletividade dos cidadãos e o herói trágico que imita os valores religiosos, políticos e sociais da ação.

Identifica-se na tragédia grega ${ }^{2}$ pelo menos três funções básicas: a expressão artística, a educação do público e a catarse. Na primeira função, a linguagem é expressa pelos conflitos; na segunda, a tragédia encena os vánios aspectos dos conflitos, que sob a forma dos diálogos procurava formar a opinião pública; e, na terceira função é demonstrado o sofrimento para alcançar a purificação das emoções. Esta função educativa foi mostrada nas tragédias de Sófocles ${ }^{3}$ como um meio para adquirir a consciência moral.

O contexto histórico grego, Sófocles em 441 a. C. escreve a a tragédia de Antígona com a finalidade de brotar os sentimentos mais profundos da alma. Nela, a ação trágica é compreendida na representação do ser humano que sofre, cuja dor proporciona emoções de terror e de compaixão para alcançar a catarse.

No período moderno da filosofia, Hegel analisa Antígona com o objetivo de explicar a trajetória do espirito diante da história reflexiva da consciência. Deste modo, é necessário desenvolver, inicialmente, o conceito da tragédia na Poética de Aristóteles, juntamente com a análise sobre os elementos qualitativos da ação trágica, a saber: mito, caráter e pensamento. Numa abordagem aristotélica da tragédia, o segundo momento demonstra a função da ação trágica na Estética de

1 No final do século VI para o V a. C. a tragédia surge na Grécia como fator decisivo sobre o pensamento sócio-político da cidade. Originalmente, o termo tragédia, vem do grego tragos: bode e odes: canto e significa "canto ao bode". Esta expressão refere-se ao sacrifício religioso à Dionisio, que representava ao deus da cidade grega. Entretanto, o conteúdo do trágico não estava vinculado as representaçōes ao deus Dionísio, mas centrado em aspectos políticos, sociais e religiosos da pólis, os quais eram descritos pelos dramaturgos em forma de mito.

Na tragédia grega, enfocam-se as relaçöes conflituosas da vida e da finitude humana, onde as questões são geradas sobre um limite entre uma ação própria e uma ação alheia que não se pode ter um controle sobre a situação. Compreende-se assim, que cada cidadāo que vive na pólis elabora suas decisões, e que a partir delas poderiam gerar conflitos entre duas ou mais vontades, como por exemplo em Antígona.

3 Nas tragédias de Sófocles, o homem toma consciência de sua ação, pois o oráculo adverte os limites entre os direitos individuais e os deveres com a pólis, onde a ação do herói trágico possui um papel fundamental no desenvolvimento da ação trágica. 
Hegel. Através da leitura da Fenomenologia do Espírito, o terceiro momento analisa os elementos do mito, do caráter e do pensamento em Antígona ${ }^{4}$ para compreender os momentos da dialética da ação trágica. ${ }^{5}$

\section{2 - A Tragédia em Aristóteles}

Na Poética, Aristóteles apresenta uma análise filosófica sobre o discurso poético, onde se definem as diversas características da natureza da tragédia, enquanto expressão da mímese (mímesis) artística. ${ }^{6} \mathrm{~A}$ mímese aristotélica possui como significado o mundo exterior com interpretações do real, onde os homens sentem prazer na imitação. Para Aristóteles, os poetas tem a função de imitar "os homens que praticam alguma ação, e estes necessariamente, são indivíduos de elevada ou baixa índole" (Poét., 1448a). A partir das relações sociais e existenciais, a mímese manifesta as ações produzidas pelo caráter humano, pois a arte imita os "caracteres, afetos e ações" (Poét., 1448a) humanas, entendidas como formas mais elevadas do belo.

Em "Aristóteles o belo é síntese de qualquer coisa moral" (Bayer, 1993, p. 48) onde a ação e a criação se processam como um conteúdo ético para alcançar o belo. Uma ação é considerada bela quando o processo da criação artística desenvolve-se através da metafísica.

Grassi analisa os aspectos aristotélicos da ação humana, conceituando a "mímesis tés práxeos não se refere portanto a qualquer ação humana, mas exclusivamente à praxe humana no sentido que o éthos the confere" (Grassi, 1975, p. 127). O objeto da mímese é a praxis ${ }^{7}$ humana onde a ação possui um sentido de revelar as possibilidades e potencialidades éticas. A poesia é apresentada no espetáculo dramático como práxis humana, identificado por Aristóteles como imitação das ações éticas mais elevadas.

Ao ser analisada como reflexo das ações, onde as emoções devem produzir um efeito elevado no espetáculo, Aristóteles define a tragédia como sendo a

4 Segundo Ross apud Ripalda (1978, p. 135) "Hegel se dedicou durante vários anos seguicios a leituras de Sófocles. Segundo mostram as traduções que todavia se conservam, com c que mais se ocupou foi Antigona, que representava para ele a forma mais perfeita da beleza e profundidade do espirito grego. Seu entusiasmo pela sublimidade e beleza dos 'passos' moral nesta tragédia se manteve durante toda sua vida". Para Ripalda "Christiane Hegel informa que a tragédia grega era a leitura favorita de Hegel na sua convalescência de algumas febres que o retiveram vários meses na casa paterna".

5 Utilizam-se neste estudo as seguintes siglas: Ant.: Antigone de Sófocles (1964); Ét. Nic.: Ética à Nicômacos (1992) e Poét.: Poética (1993) de Aristóteles; Est.: Estética (1993), LsFH: Lecciones sobre la filosofia de la história universal (1989), PhE.: Phénomenologie de l' Esprit (1991) e PrFD.: Princípios da filosofia do direito (1976) de Hegel.

Segundo F. E. Peters (1983, p. 143) o termo grego mímesis significa mimica, imitação, arte. A mimese se relaciona com a revelação da ação (praxe) na arte trágica, dentro do conteúdo aristotélico do termo. Para Alberto Diaz-Tejera (1984, p. 279) "imitar, pois, não é copiar, reproduzir. Seria um processo natural e monótono. Antes bem, significa configurar, organizar logicamente uma complexidade humana".

7 Grassi (1975, p. 126) afirma que "Praxe, pelo contrário, é toda ação completa, uma vez que tem sentido em si mesma, não sendo, portanto, um meio para alguma ccisa, já que é um fim de per si". 
"imitação de uma ação de caráter elevado, completa e de certa extensão, em linguagem ornamentada e com as várias espécies de ornamentos distribuídos pelas diversas partes [do drama], [imitação que se efetua] não por narrativa, mas mediante atores, e que, suscitando o 'terror e a piedade, tem por efeito a purificação dessas emoções'." (Poét., 1449b)

Para Aristóteles, a tragédia é um processo em que a ação ocorre dentro das paixões, misérias e agonias humanas, cujo objetivo é de preparar o homem para enfrentar as emoções mais fortes provenientes do sofrimento (páthos) ${ }^{8}$ Aristóteles entende que a mímese trágica proporciona a representação das ações humanas, cujo objetivo final é de fazer com que o espectador possa purgar as suas emoções no espetáculo.

Aristóteles reconhece que a tragédia necessita de condições apropriadas para tornar a mímese mais qualificada no seu conteúdo ético, e para tal, apresenta seis elementos fundamentais da ação trágica: mito, caráter, pensamento, elocução, espetáculo e melopéia. Destes elementos, Aristóteles caracteriza o mito, o caráter e o pensamento como qualitativos, dos quais o

"mito é imitação de ações, e por 'mito' entendo a composição dos atos; por 'caráter' o que nos faz dizer das personagens que elas tem tal ou tal qualidade; e por 'pensamento', tudo quanto digam as personagens para demonstrar o quer que seja ou para manifestar sua decisão." (Poét., 1993, 1450a).

O mito ${ }^{9}$ expressa as ações da praxe humana advindas do amor ou do ódio, onde as intrigas, os conflitos e as paixões ressaltam as possibilidades de tornar a ação qualitativa dentro dos valores manifestados no espetáculo dramático ${ }^{10}$. Deste modo, a alma da tragédia é o mito, pois a ação trágica se processa na unidade do conteúdo ético.

O segundo elemento é o caráter (éthos), ${ }^{11}$ pelo qual os personagens tomam decisões que revelam as intenções de suas ações trágicas. Revela-se, assim, um jogo trágico permitindo que o caráter se desenvolva na mímese por meio das decisões tomadas pelo herói. É por intermédio do caráter que ocorre a catarse na ação trágica.

O terceiro elemento da tragédia é o pensamento que "consiste em poder dizer sobre tal assunto o que lhe é inerente e a esse convém" (Poét., 1450b). Pelo pen-

8 Peters (1983, p. 183) define páthos como "acontecimento, experiência, sofrimento, emoção, atributo". Neste estudo, será utilizado o vocábulo sofrimento dentro do conteúdo aristotélico da ação trágica.

9 Segundo Grassi (1975, p. 123) "a raiz da palavra mythos designa portanto, o âmbito no qual falar, discorrer, fazer e pensar ainda não estão desligados, não apenas na invocação da divindade mas também no falar cotidiano (...) No significado originário de 'mythos' a palavra é também sempre acontecimento".

10 Segundo Vemant (1989, p. 37) "a palavra drama provém do dórico drân, corresponde ao ático práttein, agir. De fato, ao contrário da epopéia e da poesia lírica, onde não se desenha a categoria da ação, já que ai o homem nunca é encarado como agente, a tragédia apresenta indivíduos em situação de agir". Assim como Grassi, Vernant também analisa a tragédia como sendo a imitação de uma ação ética.

11 Para Peters (1983, p. 85) éthos significa caráter, modo de vida habitual. O autor traça um paralelo entre Platão que "é um resultado do hábito (Leis 792e)" e com Aristóteles que "é mais moral do que intelectual (diánoia) (Eth. Nich., 1139a)". Para Vernant (1989, p. 62), é dentro das "disposições de seu caráter, de seu éthos, o sujeito reage necessariamente, ex anánkes, mas é dele que emana seu ato". 
samento, a ação trágica é expressa por palavras que enfatizam as emoções mais fortes do ser humano, proporcionando a reflexão do caráter. A análise de Aristóteles permite compreender que dentro de um mundo exterior, onde existem limites da existência humana, a palavra, o modo de pensar e o.comportamento são elementos necessários para a elaboração da tragédia.

Pode-se entender que, na análise aristotélica, a unidade da ação trágica é estruturada pelo mito, caráter e pensamento. Estes elementos desempenham um papel importante para que o todo (holos) trágico desenvolva-se como um princípio, meio e fim. Este processo contribui para que o sofrimento se revele no espetáculo trágico como um meio para o desenvolvimento da ação, possibilitando que a hyoris do herói, isto é, uma força interior, seja conduzida por momentos conflitivos que se apresentam na familia (oikos) ou na cidade-estado (pólis).

Esta perspectiva permite compreender o sofrimento como sendo causado por uma dimensão existencial, proveniente de um reconhecimento da falha (hamartía) ${ }^{12}$ cometida pelo herói. Neste sentido, a função do herói trágico é dada pelo modo de agir decorrente do seu envolvimento com os sofrimentos trágicos, que possibilitam um desenvolvimento da consciência trágica.

$\mathrm{Na}$ teoria aristotélica, o sofrimento é advindo de uma condição humana e divina. Pelo humano, o caráter do herói age por sua própria determinação, enquanto que pelo divino, a sua ação é uma conseqüência do destino dos deuses. ${ }^{13}$ As ações trágicas são advindas de uma determinação divina que influencia as ações humanas para que possa ocorrer a purgação das emoções. A função das emoções é a de proporcionar a todos os que estejam assistindo o espetáculo possam apreender o significado do sofrimento. Deste modo, Aristóteles não quer apenas mostrar o sofrimento das ações trágicas, mas acrescentar a cura pela catarse (kathársis). ${ }^{14}$

Portanto, através da análise da Poética, Aristóteles interpreta a ação trágica pelos elementos qualitativos do mito, caráter e pensamento, cuja análise influenciou Hegel na formação do conceito da tragédia na Estética.

12 Segundo Brandão (1992, p. 48) hamartia significa etimologicamente "errar o alvo, com o arco e a flecha [...] 'enganar-se"'. Deve-se observar que em Édipo-Rei, a falha do herói è advinda de uma força contrária advinda da situação contingente de Édipo ao matar o Pai e casar com a própria mãe. Embora, Aristóteles não dê tanta ênfase na análise sobre Antigona, quanto a de Édipo, devese observar que ele insiste em apresentar o modo de agir decorrente do reconhecimento da ação de Antigona, como heroina na tragédia. Mas, o reconhecimento apresentado por Aristóteles é, para Hegel, a consciência. Esta análise é feita em Antígona na Fenomenologia do Espirito.

13

Os aspectos da religião estão presentes na tragédia grega, onde o sagrado infliencia as ações profanas no sentido da purgação. Contudo, percebe-se que o divino determina o destino das ações trágicas do herói. Ver neste sentido, as obras de Vernant (1989) e de Girard (1990).

14 Kathársis é definido como "purgação, purificação" (Peters, 1983, p. 121). Segundo Peters "Aristóteles deu o passo seguinte e incorporou-o na sua teoria da arte, com o resultado bem conhecido de a tragédia ser definida em termos da efetuação de uma kathársis purgação homeopática dos pathe da piedade e do medo (Poét., 1449b)". Observa-se que Aristóteles emprega a catarse dandothe uma aplicação fisiológica e médica, onde as ações são purgadas no espetáculo trágico. Para Butcher apud Lima (1980, p. 54) a catarse possui três significados: "o médico, c religioso ou litúrgico (lustratio ou expiatio) e o moral (purificatio)". 


\section{3 - A consciência artística da ação trágica em Hege]}

Na Poética, observa-se uma teoria consistente da ação trágica, formada pelos elementos do mito, caráter e pensamento. Assim como Aristóteles, o objetivo de Hegel é de verificar como estes elementos que compõem a ação trágica são compreendidos para a formação da consciência artística. Pode-se verificar na Estética que Hegel aproxima-se do conceito aristotélico da tragédia, porém, dá uma ênfase maior para o desenvolvimento da consciência da ação trágica.

Hegel concorda com Aristóteles sobre a função da mímese na ação trágica, pois o objetivo da arte não é a imitação do que ocorre na natureza, mas a revelação do conteúdo das ações humanas dentro de uma reflexão filosófica. Neste sentido, para Hegel há dois aspectos fundamentais da ação trágica, ou seja o despertar da alma e a função moralizadora da arte.

No primeiro nivel, a arte fortalece o espírito e a alma dentro dos sentimentos adormecidos no homem. Estes sentimentos devem ser situados diante das emoções mais nobres produzidas numa obra artística. No segundo nível, Hegel destaca que o fim da arte é a moralização, isto é, a purificação das emoções do homem. Tal como Aristóteles, Hegel analisa a arte com o objetivo de demonstrar que as ações humanas são purificadas pelo seu conteúdo moral. ${ }^{15} \mathrm{Na}$ função moral da arte, a alma atinge a purificação das emoções provenientes das ações humanas.

Hegel analisa a arte dentro da evolução histórica da humanidade, sendo os gregos como primeiro povo "a tomar consciência do verdadeiro trágico e do verdadeiro cômico" (Est. 1993, p. 653). Esta dimensão permite considerar a arte grega de acordo com o desenvolvimento da racionalidade. Mas, é dentro do conteúdo moral que a arte em Hegel possui como característica principal a formação da consciência artística. A arte se expressa pela história, mas desenvolve-se no interior dos contextos sociais e politicos das ações. Neste sentido, Ramiro Flórez vê na arte hegeliana a função de "alertar a alma, colocá-la em contato com todas as experiências dos grandes homens da História" (Flórez, 1983, p. 319). Hegel reconhece $\mathrm{o}$ desenvolvimento da arte grega, ${ }^{16}$ vendo nela o estatuto do belo. A arte se apresenta na história com um significado ético que ressalta a consciência para com o absoluto. ${ }^{17}$

Ao analisar a poesia dramática em Hegel, observa-se que a ação possui três aspectos fundamentais: a unidade; o modo de organização e desenvolvimento e os aspectos exteriores: dicção, diálogo e metro do verso. Quanto a unidade, Hegel considera que "Aristóteles (Poética, cap. V) ao falar da tragédia, diz apenas que a duração não deve ultrapassar a de um dia" (Est., 1993, p. 663). A unidade da ação representa a estrutura dialética da tragédia cuja finalidade é a de evoluir para a

15 Para Hegel, "a arte agiria, pois, como vivificante, como um fortalecedor da vontade moral, preparando a alma para se opor com eficácia às paixões” (Est., 1993, p. 19).

16 Assim como na Fenomenologia do Espirito e nas Liçōes da Filosofia da História, também na Estética, Hegel relaciona a tragédia com o mundo grego, pois, acredita no estágio de evolução que os gregos tiveram frente à racionalidade com a consciência de si.

17 De acordo com Terry Eagleton "a arte para Hegel não é apropriadamente representação, mas uma apresentação intuitiva que expressa uma visão, no lugar de imitar um objeto. Ela encarna uma consciência sensivel do absoluto, abolindo toda contingência e mostrando o Geist em sua inteira e orgânica necessidade" (Eagleton, 1993, p. 108). 
conciliação do trágico. Deste modo, um conflito (tese) sempre gera outro (antítese), dando origem a um terceiro (síntese) que corresponde à totalidade nas ações trágicas em conflito.

No segundo elemento, Hegel mostra a necessidade do movimento, pois "Aristóteles dizia já que um todo deve ter começo, meio e fim (Poética, cap. VII)". O começo deriva por si próprio, já o fim é conseqüência de um efeito produzido por uma causa inicial e o meio é o efeito do começo e a causa do fim. Deste modo, a unidade da ação trágica é determinada pelos conflitos estabelecidos entre os personagens, onde num primeiro momento ocorrem o nascimento das ações trágicas, em seguida, o desenvolvimento delas, e depois a conclusão da ação pelo desenlace em que se determina a resolução final do conflito. Esta análise hegeliana corresponde a uma abordagem aristotélica da unidade da ação trágica. Quanto ao terceiro aspecto, deve-se observar que é a linguagem ${ }^{18}$ dos indivíduos fortalece o diálogo no espetáculo. No diálogo, demonstram-se os caracteres vigentes das situações conflituosas, sendo esta representada por situações vivenciadas na familia ou no Estado. Deste modo, a finalidade da poesia dramática é de formar uma unidade para o despertar da consciência artística do público que a assiste.

A unidade da poesia dramática é caracterizada por Hegel como um conteúdo da ação trágica que se apresenta em dois aspectos. No primeiro, se dá pela simples consciência de quem pratica a ação e o segundo pela paixão individual em que os personagens justificam as suas ações morais. De um lado, tem-se a consciência que presenceia a ação e por outro, a paixão que se instaura como um processo emotivo. Estes dois elementos são identificados como componentes que dizem respeito às ações humanas do espetáculo trágico.

Tal como Aristóteles, Hegel analisa as ações humanas dos personagens dentro do seu caráter com a finalidade de revelar os sentimentos éticos, morais, religiosos e políticos das tramas trágicas. Para Hegel, a tragédia é caracterizada como ação humana e divina. Quanto a primeira caracterização, observa-se que o conteúdo ético das ações humanas é desenvolvido pelas lutas e os destinos presentes nos conflitos trágicos. Assim, o objeto principal da tragédia é "o direito moral da consciência no cumprimento de uma ação determinada e a justificação do ato como tal" (Est., 1993, p. 652). Identifica-se que o conteúdo da tragédia é o sofrimento trágico, caracterizado por Hegel como um páthos ${ }^{19}$ que comove e remove a existência humana dentro do espetáculo. Deste modo, o sofrimento trágico se apresenta como um conteúdo ético proveniente dos caracteres dos personagens que são desenvolvidos pelas lutas e os destinos presentes nos conflitos.

Como segunda caracteristica da tragédia em Hegel, a ação divina inspira e anima as ações humanas, pois, "o divino constitui o verdadeiro tema da tragédia primitiva" (Est., 1993, p. 647). O conteúdo da ação trágica é proveniente das verdades morais, cujo conhecimento espiritual permite o desenrolar das ações trágicas na formação da consciência, mas, "o verdadeiro conteúdo da ação trágica e dos fins perseguidos pelos autores é fornecido pelas forças universais" (Est., 1993,

18 Neste terceiro aspecto, Hegel analisa os aspectos exteriores do espetáculo, a saber: dicção, diálogo e versificação. Estes aspectos contribuem para o desenvolvimento da unidade da poesia dramática.

19 De acordo com Hegel, "podemos designar a palavra $\pi \alpha \vartheta{ }^{\circ}$ (páthos) as potências gerais que não se manifestam apenas na sua independência mas também residem vivas no peito humano e agitam a alma dos homens atè às mais intimas profundidades" (Est., 1993, p. 134). 
p. 647) que estão presentes nas situações históricas e sociais que envolvem os laços de parentesco familiar e os interesses das leis humanas. Neste aspecto, a ação trágica é inspirada pela ação divina, a qual influencia a ação humana. Hegel entende, assim, que através da determinação da ação divina na ação humana pode-se alcançar a catarse.

A respeito da ação trágica, Hegel afirma que

“Aristóteles tem razão quando diz que a ação dramática tem duas fontes (aitia duo) a reflexão e o caráter (dianoia kai éthos) é que os indivíduos não atuem para representar caracteres, mas estejam implicados na ação e se manifestem quando do desenvolvimento desta" (Est. 1993, p. 640).

Em Hegel, a reflexão (pensamento) e o caráter são elementos indispensáveis para o êxito no espetáculo dramático. Pela influência do divino na ação humana, a função do pensamento é produzir a reflexão das ações trágicas. Com o caráter, a ação trágica desenvolve-se dentro das circunstâncias determinadas pelos conflitos. Deste modo, as ações humanas e divinas produzem um conteúdo ético para o desenvolvimento da consciência da ação trágica, cujo papel é representado pelo herói face às determinações nos desenlaces dos conflitos trágicos.

Portanto, como pode-se observar através da análise da poesia dramática na Estética, a ação trágica é apresentada por Hegel dentro dos níveis da ação divina e humana. Observa-se que os elementos apontados por Aristóteles como mito, caráter e pensamento são destacados por Hegel como necessários para que a ação trágica possa se desenvolver dentro do espetáculo dramático. No mito, o divino influencia o humano dentro da história trágica. Com o caráter, apresenta-se o conteúdo das paixões humanas vividaș pelas emoções. E, pelo penșamento, ocorre a reflexão e a tomada das decisões nas ações trágicas. Embora esta análise tornase um caminho apropriado para a evolução da consciência como condição para a superação (Aufhebung) do espírito na história, Antígona é necessária como projeto que determina a consciência artística do povo grego, pois é nela que a consciência pode intuir para si a realidade da ação humana e divina.

\section{4- Autoconsciência na ação ética de antígona}

A natureza da ação trágica desenvolvida na Estética, agora é exemplificada por Hegel em Antígona na Fenomenologia do Espírito. Assim, numa abordagem aristotélica da ação trágica, torna-se necessário desenvolver os elementos mito, caráter e pensamento dentro do conteúdo ético representado em Antígona.

O mito na tragédia de Antígona de Sófocles representa a análise da consciência do espírito vivido nas relações de conflito estabelecidos entre o poder e a razão. O conflito que se estabelece em Antígona é proveniente da morte de Etéocles e Polonice, filhos de Édipo e irmãos de Antígona e Isménia. Após a morte do pai Édipo, os dois irmãos puseram-se a reivindicar o trono de Tebas, levando a um conflito entre eles. Travou-se então, uma batalha, que em luta Etéocles e Polinices acabam morrendo um pela mão do outro. Creonte, tio de Antígona assume o poder e concede as honras fúnebres apenas a Etéocles e proíbe que o corpo de Polinices tenha os rituais funerários, pois é acusado de ter traído a cidade de Tebas. 
Sofócles inicia a tragédia de Antigona, ${ }^{20}$ mostrando o conflito existencial produzido pela publicação do edito de Creonte que impede a Antígona e Isménia de realizar o ritual funerário do irmão Polinices. Segundo a tradição, a família deve enterrar os seus mortos, obedecendo um ritual divino. Embora sabendo do edito de Creonte, Antígona cumpre o seu dever, fazendo valer a lei divina e enterra Polinices. ${ }^{21}$ Ela segue sua própria consciência, mesmo tendo que desobedecer a lei da cidade. Creonte, sabedor da ação de Antígona, ordena imediatamente que o corpo de Polinices seja desenterrado e Antígona seja presa por ter desobedecido a lei humana, arrependida por não ter ajudado à irmã, Isménia recorre a Creonte para que solte Antígona. Do mesmo modo, também Hémon, filho de Creonte, intercede junto ao pai para que revogue o seu edito, e que sua noiva e prima possa viver em liberdade. Creonte não aceita tais pedidos, o que resulta numa nova ação trágica, pois Hémon, ao ver que Antígona está morta, une-se ao corpo da noiva, suicidando-se. Vendo que o seu filho estava morto, a mãe Eurídice também comete o suicídio, mas, Creonte, ao ser interpelado pelo Coro (os anciãos de Tebas), pelo corifeu (porta-voz) e ainda por Tirésias (Grande Sacerdote, chamado de divino), resolve revogar sua decisão, porém já era tarde demais, já que, mais três mortes haviam ocorrido.

Este conflito trágico ultrapassa o estágio simbólico do mito, onde a realidade existencial das ações apresenta-se como caráter dos agentes envolvidos na ação trágica. A razão e a vontade passam a ser elementos de compreensão do estágio mítico, sendo que o papel que Creonte representa é o de defender o Estado perante 0 desafio levantado por sua sobrinha Antígona em derrubar a lei por ele promulgada. Por um lado, tem-se Creonte, representante do Estado e da lei humana; e, por outro, Antígona, representante da familia e da lei divina. Inerente às funções éticas de cada um dos agentes da ação, desenvolve-se uma dialética entre a familia e o Estado, sendo analisada por Hegel dentro da lei divina e da lei humana. ${ }^{22}$

20 Deve-se verificar em Antigona três aspectos fundamentais. O primeiro é de que a familia possui um papel importante na polis, senão Antigona descendente dos Labdácidas cujo destino foi herdado do seu pai Édipo. O segundo é de que Sófocles coloca em cena a questão religiosa entre os deuses protetores da cidade e da familia. O terceiro aspecto do conflito ocorre entre a lei divina e a lei humana, isto é, entre a família e a cidade. Em Antigona, o objetivo de Sófocles è de apresentar o sofrimento de Antigona e Creonte onde o espectador vivencia a purgação das açōes desenvolvidas no espetáculo trágico.

$21 \mathrm{Na}$ tragédia, Sófocles apresenta o sofrimento de Antigona, com os seguintes versos: "Mas... de que me serve impicrar os deuses? Que auxílio deles posso receber, se foi por minha piedade que atrai sobre mim o castigo reservado aos ímpios? Se tais merecem a aprovação dos deuses, reconheço que sofro por minha culpa; mas se provém de meus inimigos, eu não lhes desejo um suplício mais cruel do que vou padecer!" (Sófocles, 1991, v. 920, p. 91).

22 Para Hegel, a lei humana está no plano da universalidade e a lei divina na singularidade. De um lado, Antigona representa os costumes (éthos) que entram em confronto com Creonte, representante da lei humana (nómos). O páthos de Antígona é diferente do páthos de Creonte, embora ambos sofram pelo envolvimento das ações e dos conflitos trágicos. Antígona sofre por não poder enterrar o seu irmão e consequentemente a sua ação diz respeito à familia, enquanto que Creonte sofre por defender as leis da cidade. Mas, quando os planos do humano e do divino sẫo dístintos, estabelece-se um conflito que dá origem à consciência da ação trágica. 
Para Hegel, a lei humana é definida como sendo a "existência universal: a comunidade; dentro de sua atividade em geral: a virilidade e, dentro de sua ativação efetiva o governo se move e se conserva porque consome em si mesmo a separação dos Penates"23 ( $P h E, 1991$, § 418, p. 322-323). A lei humana é consciente dela mesma, pois é na comunidade organizada que as formas de governo se expressam e se manifestam institucionalizadas pelas leis que se refletem no espírito universal. O governo realiza-se como espirito universal que tem seu poder na ação sobre a comunidade ética natural, a família. Por sua vez, a lei divina corresponde a ação ética que pertence ao costume da comunidade, onde a familia demonstra a sua ação pelo movimento da consciência ética natural. Assim, a personagem Antígona não só representa a consciência ética da família, mas, também a manifestação da liberdade da ação que se concretiza por enterrar o irmão. Para Jean Hyppolite, "o papel da família, da lei divina, é precisamente arrancar a morte da natureza e fazer dela essencialmente uma operação do espírito" (Hyppolite, 1991, p. 310). Tal é a natureza ética da família que a função da familia é devolver à morte o seu verdadeiro sentido, elevando a vida do espírito com o propósito de conservar a ação trágica da lei divina.

O conflito entre a lei humana e a lei divina ocorre por dois valores que segundo George Steiner são distintos entre os valores políticos (lei humana) e os valores ontológicos (lei divina). Mas, segundo Hegel, deve ocorrer um equilibrio entre o homem que desce até a prova da morte e por outro, a mulher que sobe à luz do dia para que ambos alcancem a realização da consciência na ação ética. Portanto, o movimento entre as duas consciências éticas é representada pelo caráter das ações trágicas, compreendidas como possibilidade de superação do espírito.

Como segundo elemento, o caráter ${ }^{24}$ em Antigona representa o momento da manifestação das ações trágicas apontadas por Hegel como um amor fati culpa e destino. Com características próprias da eticidade, o caráter expressa os momentos reflexivos da consciência trágica. Deste modo, a "consciência-de-si torna-se culpa. Com efeito, ela é seu agir, e o agir é sua mais própria essência" ( $P h E, 1991$, $\S 407$, p. 316). Na escolha entre as duas essências, Antigona necessariamente teve que excluir a lei humana e conseqüentemente sua ação tornou-se culpa devido a falha trágica de Édipo, pois

"a consciência ética é mais completa, sua culpa mais pura quando conhece antecipadamente a lei e a potência a que se lhe opōem, quando as toma por violência e injustiça, por uma contingência ética; e como Antigona, comete o delito sabendo o que faz." (PhE, 1991, $\S 412$, p. 319)

Antigona necessariamente teve que excluir a lei humana e conseqüentemente devido a falha trágica de Édipo sua ação tornou-se culpa. Neste sentido, Hegel vê no caráter de Antígona uma culpa que se apresenta diante do compromisso com a lei divina de enterrar o irmão. A ação de Antigona é vista como contingente, pois

23 Segundo Brandão (1993, p. 242) os penates eram "divindades tipicamente romanas, associadas a deusa Vesta, eram também protetoras da "lareira doméstica”". Em Hegel, os penates protegem a ação de Antígona diante do costume familiar de enterrar os mortos.

24 Para Hegel, "o caráter vem assim a constituir o verdadeiro centro da representação artística ideal porquanto se acham reunidos, como momentos da sua totalidade" (Est., 1993, p. 136). 
já existia uma situação criada a partir da ação de Édipo, sendo que ela foi envolvida pela vontade de enterrar o irmão. A consciência ética de Antígona é reconhecida pelo sofrimento da ação trágica por ela cometida. Neste sentido, a expressão utilizada por Hegel na F'enomenologia do verso 926 de Antígona, "é porque sofremos, que nós reconhecemos ter errado" demonstra a virtude da ação ética diante do reconhecimento da culpa. Ao ter consciência do erro, Hegel analisa a culpa de Antígona pelo reconhecimento que ela possui de sua existência.

Amélia Valcárcel entende que "Antígona reconhece a culpa como os outros heróis trágicos, porque reconhece a dor. Porém, com o sofrimento nasceu a culpa, entäo Antígona reconhece o direito de outra parte" (Valcárcel, 1988, p. 201). O que ocorre é uma dimensão existencial entre o nascer e o morrer, evidenciando por um caminho conduzido pela justiça divina, a qual se apresenta como um destino.

O destino é uma reação da vida que foi separada na tragédia, pois dela decorre a ação hostil onde nem sempre o homem percebe a relação entre o particular e o universal onde a ação se refletiu. Se, o destino joga com a realidade da consciência ética para o reconhecimento da ação, é necessánio que o herói trágico possa expiar a sua falha. Para firmar-se enquanto um ser autônomo, a ação de Antígona está influenciada por duas situações éticas que se diferenciam. Primeiro, pelo destino determinado pela força dos deuses em proteger os costumes familiares de enterrar os mortos, e, segundo, por ter que prestar obediência às determinações da lei da cidade. Neste sentido, o herói ora se vê marcada por uma visão particular proporcionada pelos deuses, ora marcada por uma perspectiva universal humana que está presente na história da consciência grega. Então, face às circunstâncias que exigem à ação, Antígona representa o destino trágico de um povo, onde aparecem o sofrimento, as lutas e o amor.

Dentro do destino, deve-se analisar o amor fati ${ }^{25}$ de Antígona diante da sua ação em enterrar o irmão. Este amor pelo irmão morto se revela como uma fatalidade humana refletida como efetividade ética das ações produzidas no interior do contexto trágico. Neste sentido, Antigona representa o papel de primazia ética frente ao direito a ela destinada como guardiã da lei divina e defensora da família.

Como terceiro elemento da ação trágica, o pensamento representa um conteúdo reflexivo dentro da representação da ação trágica de Antígona e Creonte. A razão determina o pensar do espirito que reflete sobre a consciência do saber dos costumes vigentes, sendo a lei que respalda a ação do Estado. Neste sentido, o "Espírito só é real no que tem consciência de ser; como o Estado, enquanto espírito de um povo é uma lei que penetra toda a vida desse povo, os costumes e a consciência e cultura da consciência desse povo" (PrFD., 1976, § 274, p. 250). Para Hegel, o espírito de um povo evolui na história refletindo sobre si mesmo as leis e costumes que lhe são inerentes. ${ }^{26} \mathrm{~A}$ razão determina o pensamento, desenvolven-

25 Segundo Hyppolite (1991, p. 321) "um amor fati que ao mesmo tempo é um 'morrer e renascer' donde o homem terá a mais elevada reconciliação com o destino em geral, com a história do mundo que é o que será para Hegel a suprema consciência da liberdade". Amor fati é utilizado por Hyppolite representa um amor fratemal de Antígona mesmo com a morte do irmāo Polinices, cujo destino foi dado pelos deuses.

Para Hegel "os povos são o conceito que o Espirito tem de si mesmo. Portanto, o que se realiza na história é a representação do espírito" (LsFH., 1989, p. 65). 
do-se como consciência de si através da evolução dos momentos conflitivos que procedem na Fenomenologia e que são refletidos como a manifestação da ação no estágio evolutivo da consciência do espírito. Este estágio corresponde a necessidade da "reflexão filosófica para extrair a verdade contida na forma em que os relatos históricos são apropriados" (White, 1995, p. 106-107). Assim, através das ações trágicas, as verdades são refletidas pelo espirito, desenvolvendo-se através da história da consciência.

Hyppolite analisa esta manifestação da ação ocorre a partir do pensamento, pois "no estágio em que consideramos agora, a autoconsciência somente vê na ação a necessária transição do pensado ao que é” (Hyppolite, 1991, p. 326). A consciência abandona a sua própria realidade vivida e assume a própria autoconsciência. Contudo, para que ocorra a autoconsciência, é necessário que o pensamento atue no espírito de Antígona e de Creonte produzindo no espetáculo uma ação reflexiva.

Hyppolite entende que em Hegel, o espírito apresenta-se nos grandes momentos trágicos da história, correspondendo ao movimento denominado de pantragedismo ${ }^{27}$ Esta expressão significa o processo histórico em que aparece a realidade fenomênica na filosofia hegeliana, ou seja, é um "existencialismo hegeliano, sensivel a este estudo da tragédia antiga, reconciliante ao objetivo da linguagem épica e a subjetividade do lirismo" (Hyppolite, 1971, p. 255). Entende-se, pois, que através da reflexão em Antígona, ocorre o desenvolvimento da consciência trágica na história do espírito.

\section{5 - CONCLUSÃO}

Pode-se concluir que a tragédia em Hegel possui uma abordagem aristotélica no seu conteúdo filosófico da ação trágica. $\mathrm{Na}$ análise dos elementos que compõem a tragédia, observa-se que Aristóteles desenvolve o conceito da ação trágica diante da perspectiva da mímese. Verifica-se assim, que a teoria da tragédia de Aristóteles possui um conteúdo ético na medida que a analisa as ações humanas.

Numa leitura sobre a poesia dramática na Estética, observa-se que Hegel desenvolve a noção de tragédia com uma perspectiva aristotélica. Deste modo, a ação trágica apresentada por Aristóteles na Poética é desenvolvida por Hegel na Estética como ação humana e divina. Do mesmo modo, observa-se que os elementos do mito, caráter e pensamento são desenvolvidos por Hegel na Fenomenologia na tragédia de Antígona.

No mito, identifica-se o conteúdo da lei humana e da lei divina onde se observa que a ação de Antígona está respaldada pela lei divina diante do costume familiar de enterrar os mortos, por sua vez, a ação de Creonte é determinada pela lei humana que defende as determinações do Estado. A possivel solução para este conflito, fica evidenciada dentro da análise hegeliana da ação trágica em Antígona, onde as duas leis são superadas pela consciência ética. Como segundo ele-

27 Para Hyppolite (1991, p. 320) "Hegel elabora, sem dar nome e sem tomar consciência dele, uma filosofia dialética que passará do pantragedismo do periodo da juventude ao panlogicismo da época adulta". 
mento da ação trágica, foi analisado o caráter em Antígona nos aspectos da culpa e do destino. Na primeira condição, Hegel analisa o sofrimento por não poder enterrar o irmão, onde se percebe que a culpa de Antígona não está isolada do destino determinado pelas forças divinas. No processo em que se desenvolve a ação trágica, Hegel caracteriza o divino perante os limites existenciais do encontro da vida com a morte. É um amor trágico (amor fati), que é realizado por Antígona diante do irmão morto. E, o terceiro elemento da ação trágica é compreendido como pensamento, identificado como racionalidade histórica, onde a ação ética de Antígona torna-se reflexiva.

Neste sentido, o momento da catarse em Antígona aparece como purgação do espírito em que se desenvolve na história da Fenomenologia. Pode-se dizer que foi necessário que Antígona sofresse tragicamente na história para ocorrer o desenvolvimento e a evolução do espírito. Deste modo, tanto Creonte, como Antígona são personagens que são superados na ação trágica. Esta análise permite afirmar que Antigona em Hegel é um projeto filosófico sobre o qual a ação humana tornase superada pelas experiências trágicas desenvolvidas ao longo da história da humanidade.

Portanto, numa abordagem aristotélica da ação trágica pode-se concluir que através dos elementos qualitativos do mito, caráter e pensamento, a análise hegeliana de Antígona na Fenomenologia é identificada como catarse para a formação da autoconsciência ética.

\section{Referências bibliográficas}

ARISTÓTELES. Poética. Tradução por Eudoro de Souza. 2. ed. São Paulo: Ars Poética, 1993 (ed. bilíngüe).

BAYER, Raymond. História da estética. Lisboa: Estampa, 1993.

BERTRAND, Pierre. "Le Sens du tragique et du destin dans la dialectique hégélienne". Revue de Métaphysique et de Morale, Paris, n. 1, p. 165-186, jan.

BIGNOTTO, Newton. "Tirania e racionalidade na Antigona de Sófocles". Sintese Nova Fase, Beio Horizonte, v. 20, n. 63, p. 731-744, out.-dez. 1993.

BORNHEIM, Gerd A. O sentido e a máscara. 3. ed. São Paulo: Perspectiva, 1992.

BRANDÃO, Junito de Souza. Teatro grego: origem e evolução. São Paulo: Ars Poética, 1992.

BRASS, Gérard. Hegel e a arte: uma apresentação da "Estética". Tradução por Maria X. de A. Borges. Rio de Janeiro: Jorge Zahar, 1990.

COSTA, Lígia Militz da. A "Poética" de Aristóteles: mímese e verossimilhança. São Paulo: Ática, 1992.

D’HONDT, Jacques. Hegel, filósofo de la história viviente. Tradución por Anibal C. Leal. Buenos Aires: Amorrortu Editores, 1966.

DÍAZ-TEJERA, Alberto. "La Poesia como causalidad en la Poética de Aristóteles". Revista de Linguística y Filologia clássica, Madrid, tomo 52, n. 2, p. 271-286, 1984.

DITHEY, Wilhelm. Hegel y el idealismo. Tradución por Eugenio İmaz. México: Fondo de Cultura Económica, 1978.

EAGLETON, Terry. A ideologia da estética. Tradução por Mauro Sá Rego Costa. Rio de Janeiro: Jorge Zahar, 1993.

FLÓREZ, Ramiro. La dialéctica de la história en Hegel. Madrid: Gredos, 1983.

FREITAG, Bárbara. Itinerários de Antígona: a questão da moralidade. Campinas: Papirus, 1992.

GIRARD, René. A violência e o sagrado. Tradução por Martha Conceição Gambini. São Pauì: Unesp, 1990. 
GRASSI, Ernesto. Arte como antiarte: a teoria do beio no mundo antigo. Tradução por Antonieta Scarabelo. São Paulo: Duas Cidades, 1975.

HEGEL, Georg W. F. Phénoménologie de l'Esprit. Traduction par Jean-Pierre Lefebvre. Paris: Aubier, 1991. [Phänomenologie des Geistes, 1807].

- Estética. Tradução por Álvaro Ribeiro e Orlando Vitorino. Lisboa: Guimarães Editores, 1993. [Vorlesungen über die Ästhetik, 1872].

- Enciclopédias das ciências em epitome. Tradução por Artur Morão. Lisboa: Edições 70, 1992. v. 3. [Enzyklopädie der Philosophischen Wissenschaften, 1817].

- Lecciones sobre la filosofia de la história universal. Traducción por José Gaos. Madrid: Alianza Editorial, 1989. (Vorlesungen über die Philosophie der Gerchichte, 1840].

- Lecciones sobre la filosofia de la religión. Traduccion por Ricardo Ferrara: Madrid: Alianza Editorial, 1985. v. 2. [Vorlesungen über die Philosophie der Religion. Teil 2. Einleitung; Der Begriff der Religion, 1831].

- Lecciones sobre la história de la filosofia. Traducão por Wenceslao Roces. México: Fondo de Cultura Económica, 1979. v. 2 [Vorlesungen über die Geschichte der Philosophie, 1833].

- . L' Esprit du christianisme et son destin. Traduction por Jean-Pierre Lefebvre. 8. ed. Paris: Librarie J. Vrin, 1971 [Hegels Theologische Jugendeschriften, 1907].

- La Positividad de la religion cristiana. Traduccion de Zoltan Szankay y José Maria Ripalda. México: Fondo de Cultura Económica, 1978. [Hegels Theologische Judendschriften, 1907].

- Principios da filosofia do direito. Tradução por Orlando Vitorino. 2. ed. Lisboa: Martins Fontes, 1976. [Grundlinien der Philosophie des Rechts, 1833].

HYPPOLITE, Jean. Génesis y estructura de la fenomenologia del espiritu de Hegel. Traducción por Francisco Fernández Buey. Barcelona: Península, 1991.

- Figures de la pensée philosophique. Paris: Presses Universitaires de France, 1971. v. 1.

JAEGER, Werner. Paidéia: a formação do homem grego. Traduçāo por Artur M. Parreira. 2. ed. São Paulo: Martins Fontes, 1989.

JANICAUD, Dominique. Hegel et le destin de la Grèce. Paris: Librarie Philosophique J. Vrin, 1975.

KIERKEGAARD, S - ren. La repercusion de la tragédia antigua en la moderna: un ensayo de esfuerzos fragmentários. Madrid: Guadarrama, 1969.

LESKY, Albin. A Tragédia grega. Tradução por J. Guinsburg et al. 2. ed. São Paulo: Perspectiva, 1990.

LIMA, Luiz Costa. Mimesis e modernidade: formas das sombras. Rio de Janeiro: Graal, 1980.

PETERS, F. E. Termos filosóficos gregos. Tradução por Beatriz Rodrigues Barbosa. 2. ed. Lisboa: Fundação Calouste Gulbenkian, 1983.

RIPALDA, José Maria. La nación dividida. Raices de um pensador burgues: G. W. F. Hegel. México: Fondo de Cultura Económica, 1978.

SOPHOCLE. Antigone. Traduction par Robert Pignarre. Paris: Flamarion, 1964.

STEINER, George. Les Antigones. Traduction par Philippe Blanchard. Paris: Gallimard, 1986.

TAMINAUX, Jacques. "La Pensée esthéthique du jeune Hegel". Revue philosophique de Louvain, Louvain, n. 56, p. 222-250, 1958.

VALCÁRCEL, Amélia. Hegel y la ética: sobre la superación de la "mera moral". Barcelona: Anthropos, 1988.

VERNANT, Jean-Pierre \& VIDAL-NAQUET, Pierre. Mythe et tragédie en Gréce ancienne. v. 1. Paris, Éditions La Découverte, 1989.

WHITE, Hayden. Meta-histónia: a imaginação histórica do século XIX. Tradução por José Laurênio de Melo. 2. ed. São Paulo: Edusp, 1995. (Coleção Ponta, v. 4). 